\title{
Reducing deforestation in Colombia while building peace and pursuing business as usual extractivism?
}

\author{
Torsten Krause ${ }^{1}$ \\ Lund University, Sweden
}

\begin{abstract}
In this article, I examine the contradictions and tensions in Colombia's simultaneous embrace of REDD+ and a peace-building process premised on continued extractivism. Colombia is emerging from an internal conflict that lasted more than 50 years. In this process rural land-use is being transformed, generating new conflicts over land use and control with detrimental effects on Colombia's forests. Based on official documents, reports, existing scholarly work, interviews and observations collected during fieldwork in the Colombian Amazon, I analyze the ways in which peace-building and post-conflict transition have precipitated factors which have aggravated land conflicts and led to the escalation of deforestation in Colombia. I argue that Colombia's current REDD+ efforts mainly serve to attract international funding and legitimize the status quo since they remain disconnected from the structural processes that directly and indirectly drive deforestation. As such, REDD+ in Colombia contributes to a contradictory neoliberal approach to development, which promises to safeguard the environment, while supporting large-scale extractive industries, mining, cattle ranching and intensive agriculture, resulting in the increase in deforestation and forest degradation.
\end{abstract}

Key Words: Colombia, post-conflict, peace-building, extractivism, deforestation, REDD+

\section{Résumé}

Dans cet article, j'examine les contradictions et les tensions dans l'adhésion simultanée actuelle de la Colombie à REDD+ et à un processus de consolidation de la paix fondé sur la poursuite de l'extractivisme. La Colombie sort d'un conflit interne qui a duré plus de 50 ans. Dans ce processus, l'utilisation des terres rurales se transforme, générant de nouveaux conflits sur l'utilisation et le contrôle des terres, avec des effets néfastes sur les forêts colombiennes. Sur la base de documents officiels, de rapports, de travaux universitaires existants, d'entretiens et d'observations recueillis lors de travaux sur le terrain en Amazonie colombienne, j'analyse les façons dont la consolidation de la paix et la transition post-conflit ont précipité des facteurs qui ont aggravé les conflits fonciers et conduit à l'escalade de déforestation en Colombie. Je soutiens que les efforts actuels de la Colombie en matière de REDD+ servent principalement à attirer des financements internationaux et à légitimer le statu quo, car ils restent déconnectés des processus structurels qui entraînent directement et indirectement la déforestation. En tant que tel, REDD+ en Colombie contribue à une approche néolibérale contradictoire du développement, qui promet de protéger l'environnement, tout en soutenant les industries extractives à grande échelle, l'exploitation minière, l'élevage de bétail et l'agriculture intensive, entraînant une augmentation de la déforestation et de la dégradation des forêts.

Mots clés : Colombie, post-conflit, consolidation de la paix, extractivisme, déforestation, REDD+

\section{Resumen}

En este artículo, examino las contradicciones y tensiones en la implementación simultáneo de REDD+ en Colombia y un proceso de construcción de paz basado en el extractivismo continuo. Colombia está saliendo de un conflicto interno que duró más de 50 años. En este proceso, el uso de la tierra rural se está transformando, generando nuevos conflictos sobre el uso y control de la tierra con efectos perjudiciales para los bosques de

\footnotetext{
${ }^{1}$ Dr. Torsten Krause, Lund University Center for Sustainability Studies, Lund University, Sweden. Email: torsten.krause "at" lucsus.lu.se. Acknowledgements: The author gratefully acknowledges funding from the Swedish Research Council (VR Grant Number - 2016-00583) and FORMAS (2018-00453). The author would like to thank all respondents who took part in the study. This is the first article in Adeniyi Asiyanbi and Jens Friis Lund (eds.). 2020. "Stabilizing a policy: reproducing REDD+", Special Section of the Journal of Political Ecology 27: 378-495.
} 
Colombia. Con base en documentos oficiales, informes, trabajos académicos existentes, entrevistas y observaciones recopiladas durante el trabajo de campo en la Amazonía colombiana, analizo las formas en que la construcción de la paz y la transición posterior al conflicto han precipitado factores que han agravado los conflictos por la tierra y conducen a la escalada de deforestación en Colombia. Sostengo que los esfuerzos actuales de REDD+ en Colombia sirven principalmente para atraer fondos internacionales y legitimar el statu quo, ya que permanecen desconectados de los procesos estructurales que impulsan directa e indirectamente la deforestación. Como tal, REDD+ en Colombia contribuye a un enfoque neoliberal contradictorio del desarrollo, que promete salvaguardar el medio ambiente, al tiempo que apoya las industrias extractivas a gran escala, la minería, la ganadería y la agricultura intensiva, lo que resulta en un aumento de la deforestación y la degradación de los bosques.

Palabras claves: Colombia, posconflicto, consolidación de la paz, extractivismo, deforestación, REDD+

\section{Introduction}

The role of forests in climate change mitigation has been widely acknowledged and REDD+ (Reducing Emissions from Deforestation and forest Degradation and the role of conservation, sustainable management of forests and enhancement of forest carbon stocks) remains a celebrated global mechanism in response to deforestation and forest degradation (UNFCCC 2015). However, what REDD+ is supposed to be, for instance a project of global environmental governance (Thompson et al. 2011) or a payment for environmental services scheme (Corbera 2012; Karsenty et al. 2014), and what it can and cannot do in the struggle to reduce deforestation and forest degradation, remains hotly debated (Duchelle et al. 2018; Fletcher et al. 2016; Massarella et al. 2018; Schroeder and McDermott 2014; Weatherley-Singh and Gupta 2015). Several scholars have critiqued the fundamental basis of REDD+ as an established offspring of neoliberal environmental governance that uses market-based mechanisms and carbon offsets as solutions to deforestation (Bumpus and Liverman 2011; Cabello and Gilbertson 2012; Chomba et al. 2016; Fairhead et al. 2012). They see REDD+ as expressive of a spatio-temporal fix ${ }^{2}$ that promises to ameliorate the effects of continued consumption in the global North. The initiative has been embraced by the global development and aid community (Asiyanbi and Lund 2020). Nonetheless, REDD+ has brought the challenges of reducing deforestation and forest degradation to the attention of a wider public and onto the global political agenda (UNFCCC 2015, 2016).

To date there is little evidence that REDD+ has actually reduced or will reduce deforestation and degradation of forests across the world (Carrasco et al. 2017; Duchelle et al. 2018; Hein et al. 2018). A major shortcoming of the initiative is that the different approaches and tools under the REDD+ umbrella rarely target the actual drivers of deforestation and forest degradation (Henders et al. 2018; Pendrill et al. 2019; Skutsch and Turnhout 2020; Weatherley-Singh and Gupta 2015; Zelli et al. 2014), which are mainly found in the dynamics of the global political economy and the processes that characterize globalization, for instance international trade and industrial production of agricultural products (Pendrill et al. 2019; Persson et al. 2014). Indeed, a common assumption in the literature is that REDD+ is a somewhat distinct green initiative which seeks, in principle, to out-compete or displace traditional extractivist investment (Angelsen et al. 2017; Fletcher et al. 2016). This has meant that little analytical attention has focused on the evident, if complicated coexistence of REDD+ and extractivist development in Colombia and elsewhere (Asiyanbi and Lund 2020).

In this article, I examine the contradictory co-existence of REDD+ and extractivist development in the context of Colombia's current simultaneous embrace of REDD+ and a peace-building process premised on continued extractivism. Colombia is particularly relevant for several reasons. First, Colombia is emerging from one of the longest internal armed conflicts in the world. The Colombian peace agreement was signed in 2016 between the government of Colombia and the Revolutionary Armed Forces of Colombia-People's Army (FARC-EP), which was the country's largest guerilla group and principal force during the more than five decade long Colombian war. Yet, the peace agreement has also sparked processes that resulted in a marked increase in deforestation in frontier areas where resources and lands are eyed up by large landowners, national and

\footnotetext{
${ }^{2}$ Spatio-temporal fix refers to the displacement and deferral for instance of greenhouse gas emission reductions to other countries (spatially), and over time (temporally) (see Carton 2019).
} 
international companies and other, often criminal, actors (GFW 2019; Volckhausen 2019). This challenges the goal of reducing deforestation and forest degradation (Reardon 2018), particularly because the peace agreement does not include environmental protection (Krause 2019). Second, Colombia has a negative track record of human rights violations and forced displacement (Anderson 2017; Bacca 2014; Daniels 2018; Sanchez-Cuervo and Aide 2013; Sánchez-Garzoli 2018) and the neoliberal development pursued by the Colombian government is largely in line with 'liberal peacebuilding' approaches (Richmond 2006, 2008). Under these approaches, the environment remains a low priority in the post-conflict transition, creating the conditions for new injustices and conflicts (Bocarejo and Ojeda 2016; Camargo and Ojeda 2017; EJOLT 2017; Forero and Urrea 2016; Mendoza 2017; Volckhausen 2019). Third, access to and distribution of land in Colombia is highly unequal and has been a major source of violent conflict for decades (Forero and Urrea 2016; Guereña 2017; Kirk 2009; USAID 2017).

Based on official documents, reports, scholarly work, interviews and observations collected during fieldwork in the Colombian Amazon, I attempt to reveal the inherent complexities between reducing deforestation, the post-conflict transition, and peacebuilding in Colombia. I draw on additional insights from Visión Amazonía, a regional REDD+ project that is being implemented across the Colombian Amazon region and which receives substantial financial backing from the UK, Norway and Germany. I analyze Colombia's post-conflict transition in relation to REDD + because the reconfiguration of power and territory since the peace agreement has significantly contributed to a change in natural resource exploitation at the local and national level. This change is linked to accelerated deforestation in Colombia. Moreover, the peace agreement has also turned national level development practices and priorities towards conventional large-scale natural resources extraction and economic development, while simultaneously maintaining a rhetoric of fighting deforestation and forest degradation.

I draw on a variety of sources including policy briefs, academic articles on REDD+ and on material addressing social and environmental changes in Colombia's transition towards post-conflict, national and international newspaper articles, official reports published by the Colombian government and its affiliated institutions, and international organizations. In addition, I draw on participant observation, and in-depth interviews with Indigenous representatives (3), academic experts (3), governmental environmental authorities (4) and civil society organizations (5) and that were carried out during four fieldwork stays in the Colombian Amazon region between June 2017 and February 2020. Data on deforestation was obtained from Global Forest Watch (GFW 2019).

\section{Colombia's transition towards post-conflict and its implications for forests}

From 2001 to 2015 Colombia has had one of the lowest rates of deforestation in South America, particularly in comparison to neighboring Ecuador or Brazil (FAO 2012). Based on data from Global Forest Watch, annual deforestation rates fluctuated between 0.15 and $0.33 \%$ from 2001 to 2015. However, starting from cease fire negotiations between the Colombian government and the FARC-EP in 2014 leading to the signing of the peace agreement - in the fall of 2016 - deforestation soared, up from $0.17 \%$ in 2015 to $0.52 \%$ in 2017 (GFW 2019) (see Figure 1).

Deforestation has risen most rapidly along the north-western parts of the Amazon region in the departments of Putumayo, Caquetá and Guaviare, which were former FARC strongholds and which currently experience a major wave of land-grabbing as a result of the reconfiguration of control over access to land in the post-conflict process (see Figure 2) (Armenteras et al. 2018a; IDEAM 2017). However, how can the increased deforestation trend be explained at a time when official discourses align the post-conflict peace process in Colombia with the rhetoric of reduced deforestation through REDD+? In this article I show how a range of conditions unleashed in the peace-building process, including the process of land-grabbing and the government's strategy of promoting extractivist development, have catalyzed deforestation in Colombia. Yet, as I show below, the deployment of REDD+, having little traction on the ground, appears to legitimize the status quo and does little to decrease deforestation. 


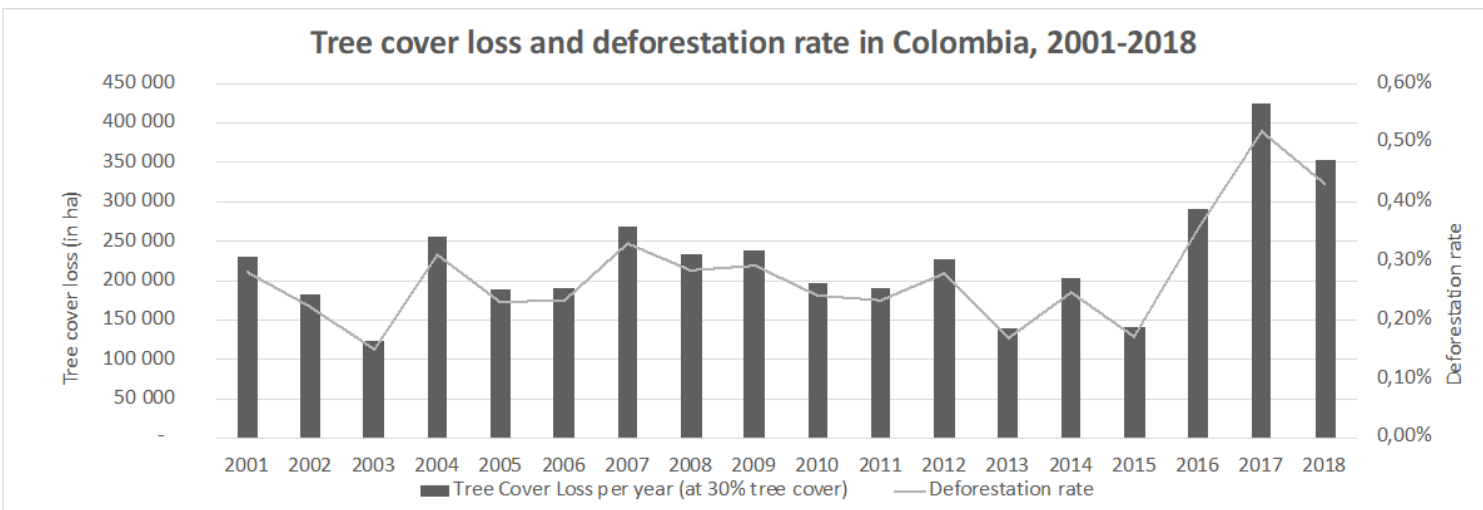

Figure 1: Tree cover loss and deforestation rate in Colombia, 2001-2018 (at 30\% canopy cover). Own elaboration based on data from Global Forest Watch, 2019. (GFW 2019)

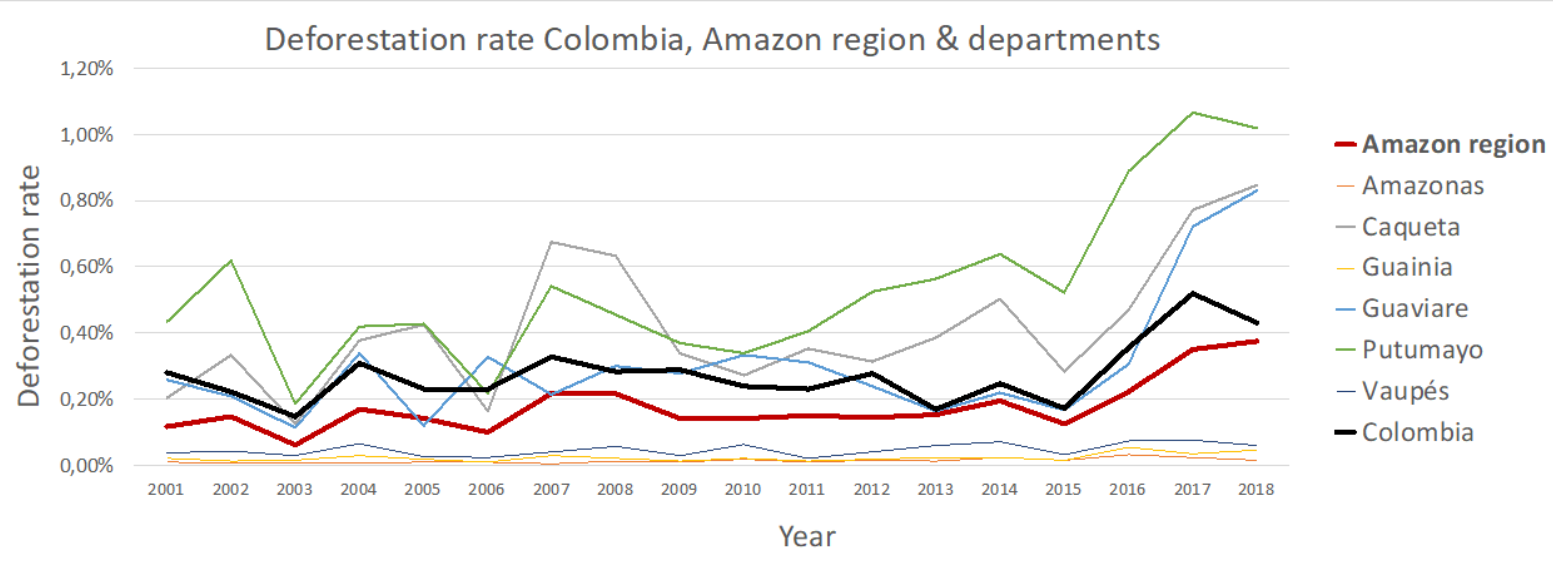

Figure 2: Deforestation rates from 2001-2018 in Colombia, the Amazon region and the six departments that encompass the Colombian Amazon. Source: Own elaboration based on data from Global Forest Watch 2019. (GFW 2019)

The armed conflict in Colombia was not only a struggle over territory, but also of competing land management policies and control over resources (Álvarez 2003), and this was a main trigger for the conflict which started in the late 1950s. Yet, over the course of the conflict, the unequal distribution of land increased. Colombia has one of the most unequal land distributions in Latin America where $1 \%$ of large farms account for $81 \%$ of the country's productive land while the other $19 \%$ of land is distributed among the remaining $99 \%$ of small landholders (Guereña 2017). For many years, the FARC was the de-facto authority in many rural areas of the country and had substantial influence over land-use decisions and other aspects of daily life (Betancur Alarcón 2019; Murillo Sandoval et al. 2020; Sanchez-Cuervo and Aide 2013).

In the wake of the 2016 peace agreement and the FARC rebel's disarmament and subsequent retraction into re-socialization camps, deforestation rose substantially in those areas that were former FARC strongholds (Armenteras et al. 2018b; IDEAM 2017; Murillo Sandoval et al. 2020; Prem et al. 2018). Some reports attribute this rise in deforestation to the sudden absence of the FARC who enforced forest protection and whose presence prevented infrastructure development, industrial agricultural production and resource extraction by national or foreign companies (Guhl 2018; Reardon 2018). 
The inability of the Colombian State to fill the void left behind by FARC implied that large landowners, peasants and new colonizers started to seize the opportunity to enlarge their landholdings and indulge in land speculation (Armenteras et al. 2018a). Burning forests and converting forest land to cattle ranching provides short-term benefits, and may pave the way for legal land titles in the longer term. Colombia's decentralized system with its regional environmental authorities has been unable to stop the ongoing grabbing of land or the construction of roads by local municipalities, even though it has been termed illegal by the central government (Baena and Correa 2017; Volckhausen 2017).

Access to land was a cornerstone of the peace agreement. The first stipulation contains the Comprehensive Rural Reform, which represents 104 commitments that form the foundation for rural development in Colombia's post-conflict transition. It includes the formalization of 7 million hectares of land (OACP 2016). Nevertheless, the KROC Institute, charged with overseeing the implementation of the accords of the peace agreement, recently published a report stating that only $2 \%$ of the 104 commitments under the rural reform and access to land have been completed, while 38\% commitments are not initiated, 51\% only minimally and 9\% partially (KROC 2019). The comprehensive rural reform is key in the post-conflict transition, but it is challenged by the increasingly unequal land ownership in Colombia (Guereña 2017; Isacson 2017). The reform, being implemented slowly, has so far failed to address the problems of growing land inequality and the related problem of increasing large-scale deforestation. Without legal land titles and the absence of a full cadaster system, land-grabbing and speculation is rife in rural areas, particularly along the Amazon frontier region. The result is forced displacements of peasant farmers, who then move into new areas to clear lands, and also large landowners seize the opportunity and move into forested areas and also stake land claims (Forero and Urrea 2016; Volckhausen 2019).

Palm oil and cattle ranching are two growing drivers of deforestation. Colombia is the largest producer of palm oil in Latin America, and fourth globally. The sector is expected to grow substantially. Oil palm contributes indirectly to deforestation because it is mostly grown on former pasture lands (Colprensa 2018). A similar dynamic has been observed in Brazil, where zero-deforestation policies for soybean production meant an expansion of cattle ranching, which grew in importance as a direct driver of deforestation (Gasparri and de Waroux 2015).

Cattle ranching is a booming major land use, and another main driver of deforestation since it expands into forest areas at the agricultural frontier (Armenteras et al. 2013, 2018a). More than half of Colombia's agricultural land is dedicated to cattle pastures and the sector is growing. While the number of cattle in Colombia has grown by 30\% since 2001, between 2017 and 2018 alone the stock of cattle grew by $11 \%$ (FEDEGAN 2018).

For decades the Colombian government and the World Bank have actively fostered extensive cattle ranching in the Amazon region as an economically productive land-use (Personal communication, CORPOAMAZONIA, December 2019). In Colombia, as in Brazil, cattle ranching is used by farmers to claim ownership over newly cleared lands. The branded cattle act as privately owned 'placeholders' (Castro-Nunez et al. 2017; Chadid et al. 2015). Several interviewees stated that cattle ranching is a strongly engrained in local cultural values and ranchers are seeking to expand their pastureland into forest areas, now undeterred by the FARC. This is a major reason for the ongoing land grabbing and associated deforestation (Personal communication, International Conservation Organization representative and CORPOAMAZONIA, December 2019).

In 2010 the World Bank approved a sustainable cattle ranching project combined with a biodiversity and carbon payment for ecosystem services (PES) scheme. This was an attempt to address the environmental degradation and land-use change associated with cattle ranching, particularly in the regions that border the Colombian Amazon (World Bank 2020). The project is implemented through the National Cattle Ranching Association, in collaboration with the Nature Conservancy Trust and connected to the REDD+ Early Movers program, Visión Amazonía (Pillar 3, see section on Visión Amazonía) (GEF 2018). However, it remains questionable whether conventional agricultural models focusing on intensifying land use and production, even if combined with silvopastoral practices, can lead to reduced deforestation. In Colombia's post-conflict context, territorial control is highly disputed and deforestation is largely caused by structures and powers that seek to 
expand their land holdings, rather than by inefficient production (Murillo Sandoval et al. 2020; Olaya 2019; Van Dexter and Visseren-Hamakers 2019).

Colombia's most infamous export product - coca (Erythroxylum coca) - adds another piece to the complex puzzle of multiple deforestation drivers (Davalos et al. 2011; Negret et al. 2019). The struggle to eradicate coca has been going on for several decades and with substantial financial, military and material support from the United States, as part of its Plan Colombia (Mejía 2016). Yet, Plan Colombia has largely failed to reduce coca production. However, the process of implementing it was accompanied by rampant State violence, and the destruction of the livelihoods of peasants who often have few alternatives to coca cultivation (Bocarejo and Ojeda 2016). Driven by international demand for cocaine, the peace agreement with the FARC, ironically, led to an increase in the production of coca, from a low of 78,000 hectares in 2012 to an estimated 209,000 hectares in 2017 (ONDCP 2018). There are several reasons for this increase. First, in the absence of the FARC-EP a range of newly formed armed groups now compete in narcotrafficking and expand coca crops into forested areas (Murillo Sandoval et al. 2020). Second, the National Comprehensive Program for the Substitution of Illicit Crops (PNIS) largely failed as a critical component of the peace agreement, and farmers who voluntarily enrolled in the program are increasingly re-planting coca which is often the only alternative crop in remote rural areas (Murillo Sandoval et al. 2020; Sadinsky and Campos Iriarte 2019). Thus, the growing of coca is another important driver of deforestation and forest degradation in Colombia that affects the frontier areas of the Amazon and Pacific region in particular (Armenteras et al. 2018a; Davalos et al. 2011; IDEAM 2017; Negret et al. 2019; Paz Cardona 2019).

The consequences of the illicit coca industry are manifold. Some scholars suggest that the production and trafficking of coca by organized crime fuels processes of land grabbing and deforestation, describing a vicious cycle where the power and ability to corrupt and intimidate is used to increase control over land (Ballvé 2012; Van Dexter and Visseren-Hamakers 2019). Ranching is, for instance, a way to launder money obtained from illegal sources (Personal interview, International Conservation Organization representative, December 2019). By some estimates, $11 \%$ of Colombia's agricultural land is controlled by narco-traffickers in a form of a rentier-agribusiness nexus (Richani 2012). In addition, there is evidence from the Putumayo region that former coca growers are using financial incentives provided by the state to replace coca crops to invest in and expand cattle ranching activities in other areas (Murillo Sandoval et al. 2020). Thus, attempts to provide alternative livelihoods to coca farmers might also end up fueling deforestation (Palmer 2017).

Another important driver of deforestation in Colombia is mining (Armenteras et al. 2018a). In 2017, Colombia was the world's fourth largest exporter of coal (IEA 2017). There are well over 100 publicly listed and private mining firms who have acquired titles in Colombia to continue the exploration for coal as well as metals, foremost gold. Moreover, in early 2017 there were 8,971 mining titles active in the country, covering $3.9 \%$ of the national territory (OBG 2017). Gold mining is widespread and causes substantial environmental pollution, negatively affects human health (Alvarez-Berríos and Aide 2015), and drives insecurity and high rates of violence in mining areas (Rodríguez and Galvis 2016). The vast majority of gold mining in Colombia is illegal and the prospect of mining and the presence of mineral resources attracts organized crime and increases the risk of violence, human rights violations, and forced displacements (DNP 2018; Leal and Morales 2013). However, the government of Colombia promotes mining by assigning legal mining titles in order to drive economic development (DNP 2014), including in Indigenous reserves in the Amazon (Prada Céspedes 2020). The most recent national development plan (2018-2022) aims to double foreign direct investment, to expand mining of minerals and coal, and to increase gold production by 43\% (DNP 2018).

It is clear that the factors unleashed in the Colombian post-conflict transition are interlinked and complex. Areas that were previously under the de facto control of the FARC, and thus under some sort of environmental control and protection, have now been opened up to investors and, in the newly-won security, large landowners are seeking to expand their landholdings (Murillo Sandoval et al. 2020; Paz Cardona 2019). So far, the Comprehensive Rural Reform has not been implemented in full (KROC 2019). Ranching has advanced into the areas formerly occupied by the FARC. The peace agreement has witnessed the expansion of coca farming. And attempts to incentivize farming away from coca has meant a shift towards ranching. The search for foreign direct investment and mineral exploration targets have also driven deforestation. In the following section, I show how REDD+, in its aims, serves to legitimize the current status quo and importantly, and how it has been 
pursued with little traction on the ground. As such, REDD+ sidesteps the complex, structural drivers of deforestation while serving to attract international finance.

\section{The making of REDD+ in Colombia}

Colombia embraced REDD+ early on, and has been involved in both the World Bank's Forest Carbon Partnership Facility (FCPF) and the UNREDD mechanism supported through the United Nations (UN-REDD 2015). The Colombian constitution recognizes and protects ethnic and cultural diversity and grants Indigenous people the right to territorial jurisdiction in their territories in accordance with their own laws and procedures, while afro-Colombian communities are granted collective land titles along the Pacific coast (Colombia 1991). Consequently, for the implementation of REDD+, the recognition of the diverse laws and procedures that apply in Indigenous and afro-Colombian territories is important and in addition to international rules that must be upheld, for instance regarding free, prior and informed consent. These communities, however, often have different views or expectations of REDD+, which influences their decision whether to participate or not (Aguilar-Støen 2015). For instance, Indigenous organizations, including COICA, that represent the different Indigenous groups of the Amazon basin, have been more critical of REDD+ from the onset and favor a culturally appropriate and territorially-based approach, which they believe would strengthen their collective rights to land (COICA 2010; Garzón 2017). Afro-Colombian communities in the Pacific region however are more aligned with the government and favor a market-based and institutional approach to REDD+ (Streck et al. 2015).

In 2011, REDD+ was integrated into the national development plan and the national REDD+ strategy was finalized (UN-REDD 2015). Since then, a relatively large number of REDD+ projects were established under the voluntary carbon market. According to the ID-RECCO database, there were 25 REDD+ projects (excluding reforestation and afforestation) registered in Colombia (Simonet et al. 2018). However, it is unclear whether these projects are actually implemented and are running in practice, as documentation for all 25 listed projects is not available. The reason for the poorly documented projects could be that many local REDD+ processes led by NGOs, development assistance agencies and private actors have run up against resistance from local communities (Aguilar-Støen 2015). Only ten projects have been registered, verified and validated according to the Community, Climate and Biodiversity standards (excluding reforestation and afforestation) according to the Voluntary Carbon Standard database, most of them located in the western part of the country in the Choco-Darién ecoregion (VCS 2018). Out of these ten projects, seven were implemented under the umbrella of the BIOREDD+ initiative in the Pacific region through funding from USAID (US\$27.8 million from 2011-2014) (USAID 2013).

The observed discrepancy between the 25 listed REDD+ projects in the ID-RECCO database and the ten projects that were registered in the VCS database can partially be explained by Colombia's decentralized environmental governance, where REDD+ is left in the hands of local authorities and private actors. This is at variance with Ecuador or Costa Rica, who have taken a much more centralized approach to REDD+ (AguilarStøen et al. 2016; MAE 2016). The decentralized governance allows private actors, i.e. 'carbon cowboys', to negotiate with Indigenous people over control of forest carbon (Aguilar-Støen 2017). This, in turn, raises questions about the impacts on recognition of Indigenous peoples' rights, and more technical aspects regarding monitoring, reporting and verification of avoided deforestation.

\section{Visión Amazonía}

In 2015, the Colombian Ministry of Environment and Sustainable Development launched a large-scale program called Visión Amazonía, which became part the existing national REDD+ strategy. Visión Amazonía has a regional focus on the Amazon region and aims to provide alternative livelihoods, strengthen environmental governance and promote Indigenous participation. The program is financially supported by various foreign countries, including Germany (GIZ and KFW), the United Kingdom (UKAID) and Norway (MINAMBIENTE 2018). Norway is one of the main funders of the project and has pledged up to US\$50 million per year until 2025, based on achieved emission reductions (Regjeringen 2018). However, the donors 
of Visión Amazonía withdrew US\$15 million of financing in 2019, because the deforestation rates increased and did not meet emission reduction targets (MINAMBIENTE 2019)

Visión Amazonía is part of the REDD+ for Early Movers program, to reduce deforestation and mitigate climate change via sustainable economic development of the frontier areas in Colombia's Amazon region. It is structured according to five pillars:

1. Forest governance - to improve the coordination of institutions, forest ordinances, planning, and command-and-control instruments for forest management.

2. Sustainable sector development - to manage the intersectoral and public-private deals for industries and extractive infrastructure in the Amazon to drive productive development that reduces deforestation and to improve the instruments of territorial management and zoning of land use. In addition, designing and implementing an incentive strategy for "green municipalities."

3. Agro-environmental development - to promote sustainable and alternative production practices, strengthen the value chain for meat, milk, rubber, cocoa and non-timber forest products, promoting productive alliances and open market access.

4. Environmental governance with Indigenous people - to promote Indigenous environmental governance with respect to traditional practices and guaranteeing cultural diversity and the forest in their territories (i.e., through Indigenous reserves).

5. Enabling conditions - to improve forest monitoring and establish a forest inventory. (MINAMBIENTE 2018)

Pillars two and three show how the program seeks to combine environmental objectives with reduced deforestation via a different development model based on conservation. While pillar two focuses on territorial planning tools and the closure of the agricultural frontier, pillar three aims at expanding rural extension services, the provision of credits to farmers, new markets for agricultural products and production chains with zero deforestation agreements. Although the effects of these interventions have not been systematically assessed, they have not been able to avert the recent soaring of deforestation. This is particularly noteworthy given that these recent years have also seen the emergence of a public - private alliance for a zero-deforestation goal in the supply chains of cocoa, oil palm, beef and milk production, agreed in 2017 (IDEAM 2017; MINAMBIENTE 2017a).

Pillar four of Visión Amazonía focuses on Indigenous people's participation, which is highly relevant since legally recognized Indigenous territories cover more than $50 \%$ of the Colombian Amazon region (RRI 2017; OPIAC n/d). Indigenous territories in Colombia are not major hotspots of deforestation, but they are often affected by land-grabbing, illegal timber extraction and the expansion of cattle ranching (Volckhausen 2019). Nonetheless, and partly in response to these outside threats, Indigenous communities of the Amazon can apply for funding for projects in order to strengthen territorial planning, Indigenous agroecological practices and Indigenous governance (Infoamazonia 2017). Ten projects were financed by Visión Amazonía with a total of US\$5.2 million for 2018 (Infoamazonia 2017). In 2019, another ten were approved and will receive approximately US\$6 million to support projects that fulfill a list of criteria, such as strengthening territorial planning, environmental governance, livelihood plans, comprehensive protection of sacred sites, food autonomy, and empowerment of women (Semana Sostenible 2018). The number of applications, the geographic distribution across the Colombian Amazon region, and the thematic range of current projects reveal that Indigenous communities embrace these opportunities for receiving state funding for local projects. At the same time they don't shy away from critiquing the state's economic development models and conservation policies. However, proposals for Visión Amazonía make conservation practices technical operations through the program's bureaucracy and complicated reporting which ultimately determines and shapes local environmental governance practices (Bianguirala 2019; West 2006).

During the implementation of Visión Amazonía, Indigenous participation was carried out through a process of consultation and roundtables. The OPIAC (Organization of Indigenous groups of the Colombian 
Amazon) was the main representative of the different Indigenous groups of the Amazon region, with a mission to ensure that all collective and individual rights of its members are recognized and respected. Nonetheless, leaders of Indigenous communities in the central Amazon voice critique of the establishment process for Visión Amazonía, arguing that they had not been able to participate (Espectador 2017). Moreover, many Indigenous communities oppose the contradictory logic of the state pursuing both REDD+ and extractivism on their lands (Personal communication, OZIP, December 2019). They perceive REDD+ and Visión Amazonía as false promises (Personal communication, Indigenous representative, January 2019: Echeverri 2016; Espectador 2017).

The Colombian post-conflict reality in many rural areas is still shaped by armed actors that exert control through violence (Global Witness 2019) and intimidation, and who are involved in land grabbing, while corruption and political opportunism prevail in many regions. Since its implementation three years ago, Visión Amazonía has made little progress in terms of reducing deforestation or changing the drivers of deforestation and land grabbing in the Amazon region (Infoamazonia 2019; Olaya 2019). Many of the actors who work with conservation initiatives in the region see Visión Amazonía as something of a paradox, being on the one hand well-funded, and on the other hand rather absent at the local level (Personal communication, National Park Authority Representative, January 2019; Personal communication, International Conservation Organization Representative, December 2019). Visión Amazonía's major challenge is to reduce deforestation in the context of Colombia's complex post-conflict reality. Multiple factors interlock, for instance land grabbing, illicit crop production, and governmental economic development policies that directly drive deforestation, but which are outside Visión Amazonía's scope.

\section{Colombia's efforts to balance peacebuilding, extractivism and conservation}

In this section, I show how Colombia's deforestation dilemma is situated in the wider context of, and the current transition towards peace. It is increasingly evident that the Colombian peace agreement between the FARC and the Colombian state did not consider forests to be a central factor during the peace-building process (Krause 2019; Murillo Sandoval et al. 2020). As I have explained, Colombia's resource wealth is eyed by many actors, including landowners, landless peasants, conservation organizations, the national government, and transnational companies, because it may mean profitable source of income, or because the remaining forests are a carbon sink in that is important for climate change mitigation. All the while, the national government is struggling to contain the spread of violence and, at least rhetorically, fight deforestation (Bocarejo and Ojeda 2016; Camargo and Ojeda 2017).

At a speech at the World Economic Forum in Davos in 2020, the Colombian president Ivan Duque proclaimed that the world can only succeed to fight climate change "if we end deforestation around the world" (El Tiempo 2020). Yet, while this pays lip-service to environmental protection, the economic policies pursued by Colombia tell a different story. Although drivers of deforestation, i.e. the extraction of oil and mining, and industrialized agriculture and infrastructure projects are identified and spelled out in the government's official documents, for instance the national development plan and the national REDD+ documents (MINAMBIENTE 2017b; Armenteras et al. 2018a; DNP 2018), the same government identifies these same drivers as the "locomotives of development" (Aguilar-Støen 2017).

Environmental and Indigenous groups, however, oppose the government's policies and have resorted to the courts to stop the ongoing environmental degradation. On April 5, 2018 the Colombian supreme court of justice presented a ruling that was seen as changing the course of environmental politics in Colombia. The court stated that the Amazon's destruction causes imminent and serious damage to present and future generations and that forests were being felled to make way for more grazing and agricultural land, as well as coca crops, illegal mining and logging. Based on this, one of the most progressive court sentences in history was passed recognizing Colombia's Amazon as a subject of rights, for instance the right to survival and integrity, granting it the same legal rights as a human being (Sentence 4360, Supreme Court of Justice 2018). This means that all Colombian citizens, regardless of whether they live in the Amazon region or not, can demand its protection before the courts. In the ruling, the importance of protecting the rights of future generations is clearly stated. Furthermore, it is not necessary to show that deforestation affects the rights of 
human beings because, in itself, it violates the rights of an entity (the Amazon) that has them. In addition, the court ordered the Colombian government to come up with action plans within four months to combat deforestation in the Amazon (Sentence 4360, Supreme Court of Justice 2018).

However, despite this landmark ruling, the Colombian government continues its extractivist policies and presents these as a sustainable development path for the country (DNP 2014, 2018). While the previous government had already begun to retreat from the goal of achieving zero-deforestation by 2020, the current government has proclaimed that it will aim for a deforestation rate of 220,000 hectares per year for the coming four years. This target clearly undermines Colombia's pledge to combat climate change through reduced deforestation (MINAMBIENTE 2017a, c; Volckhausen 2019) by maintaining the same level of deforestation as in 2017 (Ardila Sierra 2019). This flies in the face of the supreme court ruling (Supreme Court of Justice 2018), puts Colombia's commitments under the Paris Agreement at risk (MINAMBIENTE 2017c) and jeopardizes the joint declaration between Colombia and Norway, Germany and the UK for zero deforestation in the Amazon by 2020 (IDEAM 2017; MINAMBIENTE 2017a; Regjeringen 2018).

The incoherence of environmental and extractivist imperatives is also highlighted by spatial overlaps. Currently, 18 areas within protected areas of Colombia overlap with 29 oil blocks in execution and another 12 reserved and 15 available oil blocks (Guhl 2018). The ambition to finance peace building through mining and extractive industries (DNP 2014, 2018), has resulted in legal challenges to local resources sovereignty (McNeish 2017b). A recent sentence by the constitutional court for instance allows for mining projects to take place without public consultations, because mineral resources are government property and their extraction is in the national interest (Sentence C-053/19 Constitutional Court 2019; Espectador 2019). These two decisions by the supreme court on one hand and the constitutional court on the other hand reveal judicial contradictions that have repercussions for forest conservation. Moreover, adding a further contradiction, although the latest National Development Plan identifies illegal mining as a main source of environmental pollution, deforestation and social-environmental conflicts, threatening sensitive and biodiverse ecosystems, the solution put forward is not to stop mining. Rather, it is to stimulate legal mining through environmental licensing and contracts with the private sector that will allow for the 'sustainable' development of the territory (DNP 2018).

The Colombian peace agreement has been termed Pax neoliberal (Neoliberal Peace) and the structural reasons that gave rise to the conflict in the first place are still not sufficiently addressed, foremost the inequalities in land ownership, the lack of a full cadaster system and lack of legal land rights (Forero and Urrea 2016). These are the major reason for the negative social and environment impacts of the current transition to peace. There is no question that ending a conflict that lasted more than half a century is a vital achievement for Colombia. Yet, achieving lasting peace and sustainable development is not easy. The challenge will be to not repeat the experiences of other countries that experienced the destruction of native ecosystems at the hands of uncontrolled expansion of unsustainable agriculture, mining and infrastructure projects such as road construction or hydropower dams (Baptiste et al. 2017; Laurance et al. 2014; Finer et al. 2015).

The extractive imperative that the Colombian state pursues might turn out to be a Faustian bargain where the achievement of socioeconomic development at the national level is carried out at the cost of local communities and the environment. This is the case in some other countries in Latin America (Arsel et al. 2016; Cáceres 2015; Holst 2016). The current expansion of intensive land use (e.g., oil palm) and extensive cattle ranching and mining which is supported by governmental policies must be revised (Aguilar et al. 2015). This requires a shift away from large scale agriculture and natural resources extraction. Peace and social justice cannot be built at the cost of furthering environmental injustices and inequalities (McNeish 2017a).

So far, REDD+ and Visión Amazonía has not addressed the Colombian reality of unequal and often uncertain land ownership, the violence associated with control over land and resources, and the resulting friction between diverse stakeholder groups and Indigenous peoples who have different interests and visions. Reducing deforestation and forest degradation in Colombia is ultimately a matter of struggle over control of the country's vast rural territories and resources, that were the stage for the armed conflict and continue to be at the center of it. The zero-deforestation goal is being pursued through REDD+, which is supposed to generate the financial support to roll out forest conservation. However, analyzing the current situation in light of Colombia's post conflict transition is pertinent, as it sheds light on the current dynamics of economic power 
relations that drive deforestation and conflicts over land ownership and land use, fostering deforestation and violence (Van Dexter and Visseren-Hamakers 2019: Murillo Sandoval et al. 2020). In particular the Pacific coast and the Colombian Amazon are portrayed as frontier areas for the continuous expansion of Colombia's extractive economic model, based on traditional resource extraction, that also create a neoliberal approach to environmental governance through payments for forest carbon and REDD+ (Corbera 2012; McAfee 2012; Ulloa 2013).

Ulloa (2013) has analyzed how Colombia's REDD+ efforts have put Indigenous peoples' territories in the middle of the controversy around the processes of controlling nature through REDD+, allowing the restructuring of territories, stakeholders, and interests around forests. The REDD+ process has not taken into account environmental priorities, for example, biodiversity conservation (Krause and Nielsen 2019), and has disregarded cultural rights and alternative visions altogether (Ulloa 2013; Schroeder and González 2019). Visión Amazonía is yet another attempt by the state to impose its authority and enforce western ideas of territorial management and conservation onto Indigenous people (Ulloa 2013; Personal communication, Indigenous representative, January 2019).

\section{Conclusion}

In this article I have described and analyzed the challenges surrounding deforestation and forest degradation in Colombia's transition to peace. I showed how the contradictions in Colombia's policies and the zero-deforestation goal questions the possibility of achieving a lasting reduction in deforestation and forest degradation, particularly since forests were not explicitly included in the peace agreement that provides the road-map for peace-building (Van Dexter and Visseren-Hamakers 2019). Over the years, countries like Norway, Germany, the UK and many others have supported forest conservation efforts in Colombia. At the same time, the country's development strategy, and the global economy's growing appetite for resources, has implied an acceleration of mining and industrial agriculture. Colombia's embrace of REDD+ early on and the significant effort and international financial support it has received to protect forests and build peace, also led to policies that on one hand claim to reduce deforestation and support REDD+, but on the other hand undermine a more sustainable forest governance and conservation through intentionally neoliberal and resource extractive supporting policies. As such, Colombia's government is literally in a balancing act, trying to satisfy international donors who would like to see the protection of the country's ecosystems and forests, and the pressure from within the government and the private sector to allow for more natural resources extraction in the form of mining, infrastructure and industrial agriculture. All the while, new armed groups, established guerilla groups (foremost the National Liberation Army - ELN) and FARC dissidents continue to establish their control over the lucrative trade in illicit crops (mainly coca), and valuable minerals, for instance gold and coltan (Ballvé 2012; Guevara et al. 2016). With the peace agreement and the FARC's demobilization, future expectations of legal land titles have driven land grabbing and illegal land markets, resulting in the expansion of cattle ranching and coca growing into forest areas (Murillo Sandoval et al. 2020).

What I attempted to show in this article is the intricate relationship between the Colombian state's struggle for a transition towards post-conflict and the building of peace, while pushing for traditional models of economic development built on the extractivist model of growth. In contradiction to the latter, it is also situating itself as a role model in the fight against deforestation with the help of foreign donor governments. However, there are multiple challenges that Colombia faces in the transition towards a post-conflict state, evidenced in the rising violence against Indigenous and social leaders (UN 2020), the increase in cultivated areas for illicit crops (Murillo Sandoval et al. 2020), the deliberate land-grabbing by narco- and cattle farmers (Forero and Urrea 2016; Van Dexter and Visseren-Hamakers 2019), legal and illegal mining (McNeish 2017a), and state-driven infrastructure and large-scale agribusinesses (Murillo Sandoval et al. 2020; Volckhausen 2017). I argue that Visión Amazonía - as the main REDD+ initiative in the Colombian Amazon - remains but a rhetorical instrument employed by the state in order to stabilize REDD+ as a policy tool, and to impose a certain idea of environmental governance that renders local conservation technical rather than actually addressing the structural reasons for deforestation. This is because the challenges it faces are largely driven by global market demands for agricultural produce, oil, minerals and coca, as well as international and national 
economic policies, and the historical legacies that together drive environmental degradation in Colombia. Through schemes like Visión Amazonía the responsibility for forest conservation is shifted to Indigenous and local communities (Skutsch and Turnhout 2020), while the real culprits and the contradictory governmental policies that directly and indirectly incentivize environmental degradation are rarely pointed out and addressed, continuously perpetuating the climate crisis.

\section{References}

Aguilar, M., J. Sierra, W. Ramirez, O. Vargas, Z. Calle, W. Vargas, C. Murcia, J. Aronson and J.I. Barrera Cataño. 2015. Toward a post-conflict Colombia: restoring to the future. Restoration Ecology 23: 4-6.

Aguilar-Støen, M. 2015. Global forest conservation initiatives as spaces for participation in Colombia and Costa Rica. Geoforum 61: 36-44.

Aguilar-Støen, M. 2017. Better safe than sorry? Indigenous peoples, carbon cowboys and the governance of REDD in the Amazon. Forum for Development Studies 44: 91-108.

Aguilar-Støen, M., F. Toni and C. Hirsch. 2016. Forest governance in Latin America: strategies for implementing REDD. In F. de Castro, B. Hogenboom and M. Baud (eds.). Environmental governance in Latin America. London: Palgrave Macmillan. Pp. 205-233.

Álvarez, M.D. 2003. Forest in the time of violence: conservation implications of the Colombian war. Journal of Sustainable Forestry 16: 49-70.

Alvarez-Berríos, N.L. and T.M. Aide. 2015. Global demand for gold is another threat for tropical forests. Environmental Research Letters 10: 014006.

Anderson, A. 2017. Colombian peace doomed if Human Rights Defenders not protected. Irish Times. [accessed August 15 2019]

https://www.irishtimes.com/opinion/colombian-peace-doomed-if-human-rights-defenders-notprotected-1.3195978

Ardila Sierra, S. 2019. The Colombian government has failed to fulfill the Supreme Court's landmark order to protect the Amazon. Bogotá D.C.: Dejusticia: Law, Justice, Society.

Armenteras, D., E. Cabrera, N. Rodríguez and J. Retana. 2013. National and regional determinants of tropical deforestation in Colombia. Regional Environmental Change 13: 1181-1193.

Armenteras, D., T.M. González, M. Meza, J.P. Ramírez-Delgado, E. Cabrera, G. Galindo and A. Yepes. 2018a. Causas de degradación forestal en Colombia: una primera aproximación. Bogotá D.C.: Universidad Nacional de Colombia Sede Bogotá; Instituto de Hidrología, Meteorología y Estudios Ambientales de Colombia - IDEAM, Programa ONU-REDD.

Armenteras, D., L. Schneider and L.M. Dávalos. 2018b. Fires in protected areas reveal unforeseen costs of Colombian peace. Nature Ecology and Evolution 3: 20-23.

Arsel, M., B. Hogenboom and L. Pellegrini. 2016. The extractive imperative and the boom in environmental conflicts at the end of the progressive cycle in Latin America. The Extractive Industries and Society 3: 877-879.

Asiyanbi, A.P. and J.F. Lund. 2020. Policy persistence: REDD+ between stabilization and contestation. Journal of Political Ecology 27: 378-400.

Bacca, P.I. 2014. Estudio sobre Genocidio y Crímenes de Lesa Humanidad en Curso: El Caso de los Pueblos Indígenas de Colombia. Bogotá, D.C.: Organización Nacional Indígena de Colombia (ONIC).

Baena, M.P. and P. Correa. 2017. La carretera con la que quieren pavimentar el Amazonas. El Espectador. [accessed July 5 2019] http://www.elespectador.com/noticias/medio-ambiente/pavimentando-elamazonas-articulo-678316

Ballvé, T. 2012. Everyday state formation: territory, decentralization, and the narco landgrab in Colombia. Environment and Planning D: Society and Space 30: 603-622.

Betancur Alarcón, L. 2019. Peace in the peaks? Changes in water and land distribution in Colombia's southern highlands during the Post-Agreement phase. MSc thesis. Lund: Lund University. 
Bianguirala, H.D.M. 2019. Resistance in the Colombian Amazon - governmentality, indigeneity and the coloniality of project development in communities Inga of Caquetá. MSc thesis. Copenhagen: University of Copenhagen.

Bocarejo, D. and D. Ojeda. 2016. Violence and conservation: beyond unintended consequences and unfortunate coincidences. Geoforum 69: 176-183.

Bumpus, A.G. and D.M. Liverman. 2011. Carbon colonialism? Offsets, greenhouse gas reductions, and sustainable development. In R. Peet, P. Robbins and M.J. Watts (eds.). Global political ecology. London: Routledge. Pp. 203-224.

Cabello, J. and T. Gilbertson. 2012. A colonial mechanism to enclose lands: a critical review of two REDD+focused special issues. Ephemera 12: 162-180.

Cáceres, D.M. 2015. Accumulation by dispossession and socio-environmental conflicts caused by the expansion of agribusiness in Argentina. Journal of Agrarian Change 15: 116-147.

Camargo, A. and D. Ojeda. 2017. Ambivalent desires: state formation and dispossession in the face of climate crisis. Political Geography 60: 57-65.

Carrasco, L.R., T.P.L. Nghiem, Z. Chen and E.B. Barbier. 2017. Unsustainable development pathways caused by tropical deforestation. Science Advances 3.

Carton, W. 2019. "Fixing" climate change by mortgaging the future: negative emissions, spatiotemporal fixes, and the political economy of delay. Antipode 51: 750-769.

Castro-Nunez, A., O. Mertz, A. Buritica, C.C. Sosa and S.T. Lee. 2017. Land related grievances shape tropical forest-cover in areas affected by armed-conflict. Applied Geography 85: 39-50.

Chadid, M., L. Dávalos, J. Molina and D. Armenteras. 2015. A Bayesian spatial model highlights distinct dynamics in deforestation from coca and pastures in an Andean biodiversity hotspot. Forests 6: 3828.

Chomba, S., J. Kariuki, J.F. Lund and F. Sinclair. 2016. Roots of inequity: how the implementation of REDD+ reinforces past injustices. Land Use Policy 50: 202-213.

COICA. 2010. Posición Politica de COICA sobre REDD+. Quito: Coordinadora de las organizaciones indígenas de la cuenca Amazonica - COICA.

Colombia, Constitucíon de la República de Colombia. 1991. Constitucíon de 1991 con reformas hasta 2009. Bogotá: Corte Constitucional. Pp. 125.

Colprensa. 2018. Colombia es el cuarto productor de aceite de palma del mundo y el primero en América. In Agronegocios (eds.). Bogotá: Agronegocios. [accessed January 10 2020]

https://www.agronegocios.co/agricultura/colombia-es-el-cuarto-productor-de-aceite-de-palma-delmundo-y-el-primer-productor-en-america-2735403

Corbera, E. 2012. Problematizing REDD+ as an experiment in payments for ecosystem services. Current Opinion in Environmental Sustainability 4: 612-619.

Court, C. 2019. SENTENCIA C-053/19. C-053/19. Constitutional Court of the Republic of Colombia, Bogotá. [accessed December 13 2019] https://www.corteconstitucional.gov.co/relatoria/2019/C-053-19.htm

Daniels, J.P. 2018. Colombian activists face 'extermination' by criminal gangs. The Guardian. [accessed November 13 2019] https:/www.theguardian.com/world/2018/aug/23/colombian-activists-faceextermination-by-criminal-gangs

Davalos, L.M., A.C. Bejarano, M.A. Hall, H.L. Correa, A. Corthals and O.J. Espejo. 2011. Forests and drugs: Coca-driven deforestation in tropical biodiversity hotspots. Environmental Science and Technology 45: 1219-1227.

DNP. 2014. Bases del Plan Nacional de Desarollo 2014-2018. In Departamento Nacional de Planeación. Bogotá: Government of Colombia. Pp. 783.

DNP. 2018. Bases del Plan Nacional de Desarollo 2018-2022. In Departamento Nacional de Planeación. Bogotá: Government of Colombia. Pp. 945.

Duchelle, A.E., G. Simonet, W.D. Sunderlin and S. Wunder. 2018. What is REDD+ achieving on the ground? Current Opinion in Environmental Sustainability 32: 134-140. 
Echeverri, J.Á. 2016. Amazonia 2020, sin visión indígena. UN Periódico. Bogotá, D.C.: Universidad Nacional de Colombia.

EJOLT. 2017. Environmental Justice Atlas - Colombia. Barcelona: Environmental Justice Organisations, Liabilities and Trade. [accessed September 12 2019] https://ejatlas.org/country/colombia

El Tiempo. 2020. Duque en Davos, entre los temas ambientales e inversiones. El Tiempo. Bogotá. [accessed February 23 2020] https://www.eltiempo.com/politica/gobierno/asi-le-ha-ido-a-ivan-duque-en-elforo-economico-mundial-en-davos-2020-454464

Espectador. 2017. Las críticas a Visión Amazonia. El Espectador. Bogotá. [accessed July 14 2019] https://www.elespectador.com/noticias/medio-ambiente/las-criticas-vision-amazonia-articulo-690945

Espectador. 2019. Proyectos mineros podrán hacerse sin consultas populares previas. El Espectador. Bogotá. [accessed July 13 2019] https://www.elespectador.com/noticias/judicial/proyectos-mineros-podranhacerse-sin-consultas-populares-previas-articulo-839471

Fairhead, J., M. Leach and I. Scoones. 2012. Green grabbing: a new appropriation of nature? Journal of Peasant Studies 39: 237-261.

FAO. 2012. State of the World's forest 2012. Rome: Food and Agriculture Organization of the United Nations.

FEDEGAN. 2018. Cifras de referencia del sector ganadero colombiano. Federación Colombiana de Ganaderos, Bogotá DC. [accessed October 12 2019] https://www.fedegan.org.co/

Fletcher, R., W. Dressler, B. Büscher and Z.R. Anderson. 2016. Questioning REDD+ and the future of marketbased conservation. Conservation Biology 30: 673-675.

Forero, L.F. and D. Urrea. 2016. Territorial peace and land grabbing in Colombia. Agrarian and environmental Justice. Amsterdam: Transnational Insitute.

Garzón, E. 2017. Amazon Indigenous REDD+: an innovative approach to conserve Colombian forests. Mongabay. [accessed July 13 2019] https://news.mongabay.com/2017/01/amazon-indigenous-reddan-innovative-approach-to-conserve-colombian-forests/

Gasparri, N.I. and Y.L.P. de Waroux. 2015. The coupling of South American soybean and cattle production frontiers: new challenges for conservation policy and land change science. Conservation Letters 8: 290298.

GEF. 2018. Evaluation of GEF's support to mainstreaming biodiversity. Washington DC: Global Environmental Facility.

GFW. 2019. Tree cover loss in Colombia. Global Forest Watch. [accessed December 12 2019] www.globalforestwatch.org

Global Witness. 2019. Enemies of the state? How governments and business silence land and environmental defenders. Washington DC: Global Witness.

Guereña, A. 2017. A snapshot of inequality - what the latest agricultural census reveals about land distribution in Colombia. Oxford: Oxfam.

Guevara, E.L., N. Duarte and E. Salcedo-Albarán. 2016. Introduction to trafficking of gold and coltan in Colombia. Bogotá, D.C.: Vortex Foundation.

Guhl, E. 2018. Colombia's new president faces daunting environmental challenges. In A.J. Paz Cardona (eds.). Mongabay. [accessed September 5 2019] https://news.mongabay.com/2018/08/colombias-newpresident-faces-daunting-environmental-challenges/

Hein, J., A. Guarin, E. Frommé and P. Pauw. 2018. Deforestation and the Paris climate agreement: an assessment of REDD + in the national climate action plans. Forest Policy and Economics 90: 7-11.

Henders, S., M. Ostwald, V. Verendel and P. Ibisch. 2018. Do national strategies under the UN biodiversity and climate conventions address agricultural commodity consumption as deforestation driver? Land Use Policy 70: 580-590.

Holst, J. 2016. colonial histories and decolonial dreams in the Ecuadorean Amazon: natural resources and the politics of post-neoliberalism. Latin American Perspectives 43: 200-220. 
IDEAM. 2017. Esfuerzos del país se concentran en alcanzar meta de zero deforestación. In MINAMBIENTE (eds.). Sala de Prensa. Bogota, D.C.: Colombian Institute of Hydrology, Meteorology and Environmental Studies - IDEAM.

IEA. 2017. Coal 2017: analysis and forecasts to 2022. Paris: Organisation for Economic Co-operation and Development (OECD) and International Energy Agency (IEA).

Infoamazonia. 2017. Los 10 proyectos indígenas que financiará Visión Amazonía en 2018. Infoamazonia. [accessed April 6 2019] https://infoamazonia.org/es/2017/11/espanol-los-10-proyectos-que-financiaravision-amazonia-para-2018/\#!/map=49\&story=post-17302

Infoamazonia. 2019. Las cuentas pendiented de Visión Amazonia, el programa contra deforestación del gobierno. El Espectador, Bogotá, D.C.

Isacson, A. 2017. Colombia's peace accords point the way to a solution. But will they be implemented? Drugs and peace in Colombia. Washington DC.: Brookings Institution.

Karsenty, A., A. Vogel and F. Castell. 2014. "Carbon rights", REDD+ and payments for environmental services. Environmental Science and Policy 35: 20-29.

Kirk, R. 2009. Colombia - human rights in the midst of conflict. In E.F. Babbitt and E.L. Lutz (eds.). Human rights and conflict resolution in context. Syracuse: Syracuse University Press. Pp. 23-45.

Krause, T. 2019. Forest governance in post-agreement Colombia. In G. Almered Olsson and P. Gooch (eds.). Natural resource conflicts and sustainable development. London: Routledge.

Krause, T. and R. M. Nielsen. 2019. Not seeing the forest for the trees: the oversight of defaunation in REDD+ and global forest governance. Forests 10.

KROC. 2019. Estado efectivo de implementación del Acuerdo de Paz en Colombia 2 años de implementación. Notre Dame: Keough School of Global Affairs.

Leal, M.C. and J.F. Morales. 2013. Implicaciones ambientales y sociales del modelo extractivista en Colombia. Contraloría General de la República.

MAE. 2016. Bosques para el Buen Vivir - Plan de Acción REDD+ Ecuador (2016-2025). Quito.

Massarella, K., S.M. Sallu, J.E. Ensor and R. Marchant. 2018. REDD+, hype, hope and disappointment: The dynamics of expectations in conservation and development pilot projects. World Development 109: 375-385.

McAfee, K. 2012. The contradictory logic of global ecosystem services markets. Development and Change 43: 105-131.

McNeish, J.-A. 2017a. Extracting justice? Colombia's commitment to mining and energy as a foundation for peace. The International Journal of Human Rights 21: 500-516.

McNeish, J.-A. 2017b. A vote to derail extraction: popular consultation and resource sovereignty in Tolima, Colombia. Third World Quarterly: 1-18.

Mejía, D. 2016. Plan Colombia: an analysis of effectiveness and costs. Center for 21st Century Security and Intelligence - Latin America Initiative.

Mendoza, M.L. 2017. La paz: reto y oportunidad frente a la deforestación. El Tiempo, Bogotá. [accessed July 5 2019] http://www.eltiempo.com/vida/medio-ambiente/la-paz-es-una-oportunidad-para-frenar-ladeforestacion-en-colombia-111914

MINAMBIENTE. 2017a. Acuerdos cero deforestación. Bogotá, D.C.: Gobierno de Colombia, Ministeria de $\begin{array}{llllll}\text { Ambiente } & y & \text { Desarollo } & \text { Sostenbible } & \text { [accessed } & \text { July }\end{array}$ https://www.minambiente.gov.co/index.php/acuerdos-cero-deforestacion\#documentos-deinter\%C3\%A9s

MINAMBIENTE. 2017b. bosques territorios de vida - estrategia integral de control a la deforestación y gestión de los bosques. Bogotá, D.C.: Gobierno de Colombia, Ministerio de Ambiente y Desarollo Sostenible and IDEAM, n/a.

MINAMBIENTE. 2017c. Política nacional de cambio climático. Bogotá, D.C.: Ministerio de Ambiente y Desarollo Sostenible. P. 290. 
MINAMBIENTE. 2018. Visión Amazonía. Bogotá, D.C.: Ministerio de Ambiente y Desarollo Sostenible [accessed July 4 2019] http://visionamazonia.minambiente.gov.co/en/

MINAMBIENTE. 2019. Ejecución Presupuestal Visión Amazonía. In Visión Amazonía. Bogotá, D.C.: Ministerio de Ambiente y Desarollo Sostenible [accessed July 4 2019] http://visionamazonia.minambiente.gov.co/ejecucion-presupuestal/

Murillo Sandoval, P.J., K. Van Dexter, J. Van Den Hoek, D. Wrathall and R. Kennedy, E. 2020. The end of gunpoint conservation: forest disturbance after the Colombian peace agreement. Environmental Research Letters 15: 034033.

Negret, P.J., L. Sonter, J.E.M. Watson, H.P. Possingham, K.R. Jones, C. Suarez, J.M. Ochoa-Quintero and M. Maron. 2019. Emerging evidence that armed conflict and coca cultivation influence deforestation patterns. Biological Conservation 239: 108176.

OACP. 2016. Acuerdo final para la terminación del conflicto y la construcción de una paz estable y duradera. Bogotá, D.C: Gobierno de Colombia. P. 310. [accessed April 20 2019] http://www.altocomisionadoparalapaz.gov.co/procesos-y-conversaciones/Paginas/Texto-completodel-Acuerdo-Final-para-la-Terminacion-del-conflicto.aspx

OBG. 2017. The report - Colombia 2017. Oxford Business Group, London. [accessed December 15 2019] https://oxfordbusinessgroup.com/overview/dig-it-reinvigorated-industry-receiving-strong-statesupport

Olaya, C. 2019. La reducción en deforestación ni es gracias al gobierno. n/a: La Silla Vacia. [accessed January 25 2020] https://lasillavacia.com/silla-llena/red-verde/la-reduccion-deforestacion-no-gracias-algobierno-71287

ONDCP. 2018. New annual data released by White House drug policy office shows record high cocaine cultivation and production in Colombia. Washington D.C.: Office of National Drug Control Policy. [accessed December 13 2019] https://www.whitehouse.gov/briefings-statements/new-annual-datareleased-white-house-drug-policy-office-shows-record-high-cocaine-cultivation-productioncolombia/

OPIAC. n/d. Miembros de la OPIAC. Bogotá, D.C.: National organisation of Indigenous People in the Colombian Amazon. [accessed December 13 2019] https://opiac.org.co/organizaciones/

Palmer, L. 2017. "It's a perverse system": how Colombia's farmers are reforsting their logged land. The Guardian. $\quad$ London. $\quad$ [accessed December $13 \quad 2019$ ] https://www.theguardian.com/environment/2017/dec/29/its-a-perverse-system-how-colombiasfarmers-are-reforesting-their-logged-land

Paz Cardona, A.J. 2019. As the Amazon burns, Colombia's forests decimated for cattle and coca. Mongabay. [accessed December 13 2019] https://news.mongabay.com/2019/09/as-the-amazon-burns-colombiasforests-decimated-for-cattle-and-coca/

Pendrill, F., U.M. Persson, J. Godar and T. Kastner. 2019. Deforestation displaced: trade in forest-risk commodities and the prospects for a global forest transition. Environmental Research Letters 14: 055003 .

Persson, U.M., S. Henders and C. Cederberg. 2014. A method for calculating a land-use change carbon footprint (LUC-CFP) for agricultural commodities - applications to Brazilian beef and soy, Indonesian palm oil. Global Change Biology 20: 3482-3491.

Prada Céspedes, E. 2020. Defensores de los cerros sagrados. Agenda Propia. [accessed February 13 2020] https://www.connectas.org/especiales/defensores-cerros-sagrados/

Prem, M., S. Saavedra and J.F. Vargas. 2018. End-of-conflict deforestation: evidence from Colombia's peace agreement. Bogotá, D.C.: Universidad de Rosario.

Reardon, S. 2018. FARC and the forest: peace is detroying Colombia's jungle - and opening it to science. Nature 558: 2.

Regjeringen. 2018. Joint statement between President Santos and Prime Minister Solberg. Extending the climate and forest partnership. Leticia, Colombia: The Government of Norway. 
Richani, N. 2012. The agrarian rentier political economy: land concentration and food insecurity in Colombia. Latin American Research Review 47: 51-78.

Richmond, O.P. 2006. The problem of peace: understanding the 'liberal peace'. Conflict, Security and Development 6: 291-314.

Richmond, O. P. 2008. Reconstructing the liberal peace. In V. Rittberger and M. Fischer (eds.). Strategies for peace, contribution of International Organizations, States and Non-State Actors. Germany: Barbara Budrich Publishers.

Rodríguez, C.A. and S.R. Galvis. 2016. El oro, la contaminación y los seres del agua. Visiones locales de los impactos ambientales de la minería en el mundo acuático de la Amazonia Colombiana. Tropenbos Internacional Colombia.

RRI. 2017. Tenure data and tool - Colombia. Washington D. C.: Rights and Resources Initiative. [accessed July 13 2019] http://rightsandresources.org/en/work-impact/tenure-data-tool/\#.WaUmCI7Cl7H

Sadinsky, S. and R. Campos Iriarte. 2019. Broken promises in Colombia's Coca fields. Open Society Foundations. [accessed December 13 2019] https://www.opensocietyfoundations.org/voices/brokenpromises-in-colombias-coca-fields

Sanchez-Cuervo, A. M., and T.M. Aide. 2013. Consequences of the armed conflict, forced human displacement, and land abandonment on forest cover change in Colombia: a multi-scaled analysis. Ecosystems 16: 1052-1070.

Sánchez-Garzoli. 2018. December update: at least 120 acitivists killed in Colombia so far this year. Washington D.C.: Washington Office on Latin America (WOLAN). [accessed December 13 2019] https://www.wola.org/2018/12/december-update-least-120-activists-killed-colombia-far-year/

Schroeder, H. and N.C. González. 2019. Bridging knowledge divides: the case of indigenous ontologies of territoriality and REDD+. Forest Policy and Economics 100: 198-206.

Schroeder, H. and C. McDermott. 2014. Beyond carbon: enabling justice and equity in REDD+ across levels of governance. Ecology and Society 19.

Simonet, G., A. Agrawal, F. Bénédet, M. Cromberg, C. de Perthuis, D. Haggard, N. Jansen, A. Karsenty, W. Liang, P. Newton, A.-M. Sales, B. Schaap, C. Seyller and G. Vaillant. 2018. ID-RECCO, International Database on REDD+ projects and programs, linking economic, carbon and communities data. CIFOR - CEC-CIRAD-IFRI. [accessed December 14 2019] http://www.reddprojectsdatabase.org

Skutsch, M. and E. Turnhout. 2020. REDD+: If communities are the solution, what is the problem? World Development 130: 104942.

Sostenible, S. 2018. Más recursos para proyectos indígenas de la Amazonia colombiana. Semana Sostenible. Semana, Bogotá, D.C. [accessed July 13 2019] https://sostenibilidad.semana.com/medioambiente/articulo/mas-recursos-para-proyectos-indigenas-de-la-amazonia-colombiana/42032

Streck, C., D. Conway, J.P. Castro and T. Varns. 2015. The impacts of international REDD+ finance Colombia case study. Climate and Land Use Alliance.

Supreme Court of Justice. 2018. STC4360-2018. Bogota D.C.: Supreme Court of Justice, Bogota.

Thompson, M. C., M. Baruah and E.R. Carr. 2011. Seeing REDD+ as a project of environmental governance. Environmental Science and Policy 14: 100-110.

Ulloa, A. 2013. Controlando la naturaleza: ambientalismo transnacional y negociaciones locales en torno al cambio climático en territorios indígenas en Colombia. Iberoamericana 13: 17.

UN. 2020. Colombia: 'Staggering number' of human rights defenders killed in 2019. United Nations. [accessed Febuary 28 2020] https://news.un.org/en/story/2020/01/1055272

UN-REDD. 2015. UN-REDD Colombia National Programme Document. Bogota D.C.: Ministry of Environment and Sustainable Development.

UNFCCC. 2015. Adoption of the Paris Agreement - draft decision -/CP.21. Paris: United Nations Framework Convention on Climate Change. 
UNFCCC. 2016. Key decisions relevant for reducing emissions from deforestation and forest degradation in developing countries (REDD+). UNFCCC.

USAID. 2013. Colombia Program at a glance. Washington D.C.: United States Agency International Development.

USAID. 2017. Colombia - property rights and resource governance. USAID Country Profile. Washington D.C.: United States Agency International Development.

Van Dexter, K. and I. Visseren-Hamakers. 2019. Forests in the time of peace. Journal of Land Use Science 116.

VCS. 2018. Project Database. Voluntary Carbon Standard. Washington, D.C. [accessed July 15 2019] https://www.vcsprojectdatabase.org/\#/projects

Volckhausen, T. 2017. Rebel road expansion brings deforestation to remote Colombian Amazon. Mongabay. [accessed July 15 2019] https://news.mongabay.com/2017/05/rebel-road-expansion-bringsdeforestation-to-remote-colombian-amazon/

Volckhausen, T. 2019. Land grabbing, cattle ranching ravage Colombian Amazon after FARC demobilization. In M. Erickson-Davis (ed.). Mongabay Series: Forest Trackers. Mongabay. [accessed October 22 2019] https://news.mongabay.com/2019/05/land-grabbing-cattle-ranching-ravage-colombian-amazon-afterfarc-demobilization/

Weatherley-Singh, J. and A. Gupta. 2015. Drivers of deforestation and REDD+ benefit-sharing: a metaanalysis of the (missing) link. Environmental Science and Policy 54: 97-105.

West, P. 2006. Conservation is our government now - the politics of ecology in Papua New Guinea. Durham: Duke University Press.

World Bank. 2020. Mainstreaming sustainable cattle ranching. Washington, DC: The World Bank. [accessed March 12 2020] https://projects.worldbank.org/en/projects-operations/document-detail/P104687

Zelli, F., D. Erler, S. Frank, J.I. Hein, H. Hotz and A.M.S. Cruz-Melgarejo. 2014. Reducing Emissions from Deforestation and Forest Degradation (REDD) in Peru: a challenge to social inclusion and multi-level governance. Bonn: German Development Institute. 